\title{
When Business Met Politics
}

The Case of Want Want, a Different Type of Media Capital in Taiwan

\section{Lihyun Lin and Chun-Yi Lee}

\section{(2) OpenEdition}

\section{Journals}

Electronic version

URL: http://journals.openedition.org/chinaperspectives/7333

ISSN: 1996-4617

\section{Publisher}

Centre d'étude français sur la Chine contemporaine

\section{Printed version}

Date of publication: 1 June 2017

Number of pages: $37-46$

ISSN: 2070-3449

\section{Electronic reference}

Lihyun Lin and Chun-Yi Lee, «When Business Met Politics », China Perspectives [Online], 2017/2 | 2017,

Online since 01 June 2018, connection on 28 October 2019. URL : http://journals.openedition.org/

chinaperspectives/7333

(C) All rights reserved 


\title{
When Business Met Politics
}

\author{
The Case of Want Want, a Different Type of Media Capital in Taiwan
}

\section{LIHYUN LIN AND CHUN-YI LEE}

\begin{abstract}
Since 2008, the Taiwanese business group Want Want, having made a fortune in China, has returned to Taiwan to buy a major media group and attempt to exert political influence on Taiwanese society. This paper analyses the rise and rationale of this new type of media investor in the light of the business-government relationship under China's model of state capitalism. According to the analysis developed in this paper, when China needed foreign investment in the early 1990s, Taiwanese investors were warmly welcomed by the Chinese government, which provided Taiwanese businesses with tax incentives at that time. After 2000, however, when not only domestic Chinese entrepreneurs emerged but also more non-Chinese investors entered the Chinese markets, Taiwanese businesses realised that the investment environment had become much more competitive, so they had to work hard on building ties with Chinese officials. Under these circumstances, Want Want bought into media in Taiwan as an asset to be used in order to build social ties with the Chinese government, but in doing so, Want Want has also triggered resistance from Taiwanese civil society. Future researchers and regulators can continue to watch and define this new type of investment, which has become increasingly significant in this region.
\end{abstract}

KEYWORDS: Taiwanese business, Taiwan, media merger, media monopoly, cross-Strait relations, government-business relations.

\section{Introduction}

F rom 1987 to the present, Taiwanese investment in China has undergone dramatic changes. As emphasised in this special issue, actors, values, and change are three core elements we constantly reflect upon in order to analyse the processual changes in Taiwan. In this paper, we aim to reveal the long-term evolution of cross-Strait economic activities. Actors who participated in this long-term process (from the end of the 1980s until now) include Taiwanese business people (Taishangs ${ }^{(1)}$ ), and the governments in both Taipei and Beijing. We argue that Taishangs' values have changed during this long-term process. When the Chinese government needed foreign investment in the early 1990s, Taiwanese investors were warmly welcomed by the Chinese government and were thus content to pursue mainly economic interests. However, after 2000, with the emergence of domestic Chinese entrepreneurs and non-Chinese investors in the Chinese markets, Taishangs had to build closer political ties with Chinese officials in order to protect their economic interests in China. Some Taishangs even adopted the strategy of buying media in Taiwan as social assets to strengthen political ties with Chinese officials. For example, a Taiwanese technology tycoon, Cher Wang, the owner of HTC Corporation, which has substantial investments in China, has gradually taken ownership of Taiwan's leading cable channel group, TVBS, since 2011. Likewise, a Taiwanese processed foods conglomerate, Ting Hsin Food Group, which developed its business in China in 1990, also attempted to acquire a major cable TV operator in Taiwan in 2014. (2) The Want Want group is a critical case to illustrate the strategy adopted. This group purchased a cross-media group in Taiwan, ${ }^{(3)}$ which allowed it to serve as a messenger to deliver the pro-Chinese government's political ideology in Taiwan. It was therefore able to use Taiwanese media as an asset to build ties with Chinese officials at the cost of local resistance from Taiwan. We acknowledge that the Want Want group might be an extreme case in indicating the changing values of Taishangs, however, we take it as an example of how the dynamic of political economy across the Strait has caused business interests to become intertwined with the government's political goals.

The Want Want group, which was originally established in Taiwan and moved its business to China in 1992, later returned to Taiwan to buy Taiwan's main media group. Want Want further attempted to buy a major multiple system operator (MSO, referring to an operator that owns several cable systems) in a market where more than $80 \%$ of homes watch cable television. This merger later resulted in the island's biggest demonstration against media monopoly on 1 September 2012.

Want Want's investment in Taiwan's media had a different rationale from that of previous Taiwanese business groups. According to related literature, previous Taishangs in China mainly followed the economic rationale. They wanted to maximise profits and reduce costs, so they moved to China and seldom returned to invest in Taiwan. They focused on their own business and did not invest in media-related concerns. They maintained good relations with all parties and did not offend local communities. (4) However, while Want Want's headquarters, factories, and revenues remained in China, ${ }^{(5)}$ the company came back to Taiwan and invested in the media business. It should be noted that investing in the media is a costly and risky en-

1. Taishangs are known as Taiwanese business people; in this paper we use Taishangs to replace Taiwanese business people.

2. In 2011 , Cher Wang bought a $26 \%$ stake in TVB, Hong Kong's leading free-to-air broadcaster. As TVB was the parent company of TVBS, a major cable channel family in Taiwan, Wang also became part-owner of TVBS. In 2016, Wang bought the remaining shares of TVBS at the cost of NT\$130 billion. Hsu Yi-Ping, "Cher Wang buys TVBS for 130 billion dollars," Liberty Times, 20 October 2016, http://news.ltn.com.tw/news/focus/paper/1046492 (accessed on 2 January 2017)

3. The China Times group include two newspaper titles, one terrestrial television station and a cable channel family.

4. Chun-Yi Lee, "Between Dependency and Autonomy - Taiwanese Entrepreneurs and Local Chinese Governments," Journal of Current Chinese Affairs (China aktuell), Vol. 39, No. 1, 2010, pp. 37-71.

5. Want Want China Holdings Limited, "Annual Report, 2015," 2015, http://www.want-want.net/upload/Investor/C16020406.pdf (accessed on 10 May 2016). 
deavour; Want Want paid NT\$20.4 billion (around US\$680 million) to buy the China Times media group, and it took almost NT\$80 billion (around US\$2.4 billion) to buy the main cable operator. While Taiwan has respected press freedom since the lifting of martial law in 1987, Want Want used this media freedom to deliver the pro-Chinese government's political ideology. ${ }^{(6)}$ Its chairman, Tsai Eng-Meng (蔡衍明), used the media to attack those he deemed enemies, including legislative regulators, journalists, and citizen groups. ${ }^{(7)}$

Concerning this type of media investor, there are at least two existing explanations, each with specific policy implications. The first explanation is that Taiwanese capital has recovered media ownership from foreigners. The Taiwanese government has loosened its regulation over media ownership, and foreign investors have been allowed to own up to $60 \%$ of cable systems since 2002. Since then, Taiwanese cable systems have mainly been owned by foreign companies. The owner of the Want Want group often describes himself as a Taiwanese coming back to boost Taiwan's economy and to improve cross-Strait relations. ${ }^{\left({ }^{8}\right)}$ From this perspective, Taiwanese regulators should welcome the company's return for its ability to reclaim Taiwan's cable TV industry from foreign investors (the private companies that have bought and sold Taiwan's cable companies), and treat them as Taiwanese nationals.

The second explanation completely rejects the first, arguing that this type of capital can be described as "Red capital." It is argued that Want Want, although established in Taiwan, has become deeply rooted in China and transmits a pro-Chinese government political ideology. Some opposition politicians have pointed out that $93 \%$ of Want Want's revenue was generated from the Chinese market and that the Want Want group is traded on the Hong Kong stock market; therefore the Want Want group should be considered a Chinese industry. ${ }^{(9)}$ According to this interpretation, Taiwanese regulators should consider Mr. Tsai a Chinese capitalist and should not allow him to buy Taiwan's cable systems, because Chinese business people are not allowed to enter this market according to Taiwanese law.

However, both interpretations fail to explain how this type of media investment emerged, nor can they fully explain why Want Want voluntarily provided ideological services to the Chinese government. The debatable point of these two explanations also lies in the definition of the capital owner's nationality. In line with the three main elements of this special issue, this article asks: what kind of Taiwanese businessmen does Want Want represent? How did it emerge? What are the main rationales for its practices? There is no doubt that Taishangs - in our example, the Want Want group - are the agents of this change. By tracing the process of the Want Want group's emergence in Taiwan and its subsequent investment in China, we aim to identify the changing nature of business's interaction with government; more specifically, in our case, of Taishangs with the Chinese government.

This paper argues that before 2008, Want Want mainly followed an economic logic and expanded in many provinces. However, under Chinese state capitalism, Want Want needed to build ties with the Chinese central government. When the CCP conducted its "Grand Overseas Propaganda" Campaign in 2008, co-opting Chinese private capitalists to acquire media abroad, Want Want acquired Taiwanese media and imposed a firm "proChina" stance on the media outlets purchased by the group; however, in doing so it encountered severe local resistance in Taiwan, where $60 \%$ of the population considered themselves Taiwanese (not Chinese), and another $85 \%$ wanted either de-jure independence or de-facto independence from
China. ${ }^{(10)}$ The empirical data for this paper come from long-term interviews with Taishangs in China, including three field trips in 2004-2005, 20082009, and 2014-2016 respectively. In the first two field trips, the interviewees were Taishangs in China, most of them members of Taiwanese Businessmen Association (TBA) in various cities, investing in a range industries such as manufacturing, biotechnology, furniture, footwear, toys, etc. The latest fieldwork (2014-2016) concentrated on ICT manufacturers in China - for instance, manufacturers of panel, of parts and components for computers or mobile phones, and of semi-conductors - and also a small percentage of software designers. The locations of the interviews were Tianjin, Beijing, Shanghai, Kunshan, Dongguan, and Taipei. The reason for combining three periods of interviews in this paper is to compare Taishangs' values in different periods, along with their efforts in building or maintaining relationships with local Chinese officials, in order to answer the core question: why and how Taishangs changed their strategies to secure their economic interest in China. Three periods of interview data provide a grand background to Want Want's emergence, and to be more specific, we also combine observations from the media about Want Want. The most recent field trip was funded with the generous support of the Chiang Ching-kuo Foundation for International Scholarly Exchange as well as the Ministry of Science and Technology, Taiwan. The structure of this paper is as follows: the next section introduces a brief theoretical framework, which mainly focuses on three different approaches to business and government relationships and also more importantly, a particular focus on why media are a valuable investment for capitalists. The second section documents the history of Want Want's investment in China within the bigger picture of Taiwanese investment in China. This is followed by discussion and analysis, and the final section serves as a conclusion.

\section{The government-business relationship and the special characteristics of media investment}

Before we start to discuss the government-business relationship, it is important to note that in the case of Want Want, there are two governments involved: the Chinese (or Beijing) government and the Taiwanese (or Taipei) government. (11) We acknowledge that in terms of the Chinese government, there is empirical evidence that local governments' interests conflict with the central government's. ${ }^{12)}$ Nevertheless, in this paper we treat the interests and goals of China's central and local governments as one. In the fol-

6. Chin-Hwa Chang, "Analysis of the News Placement and Coverage of Three Chinese Buying Groups by Taiwan's Four Main Newspapers from the Perspective of Van Dijk's Discourse and Manipulation Theory," Chinese Journal of Communication Research, No. 20, 2011, pp. 65-93.

7. "Tsai Eng Meng: My Reasons for Buying Media," Hwa Xia Net, 13 December 2013, http://big5.huaxia.com/tslj/rdrw/2013/12/3660484_3.html (accessed on 10 May 2016).

8. Ibid.

9. Hsin-Yi Huang, "Pan-Green Legislators Point out the Invasion of Chinese Capital in China Times," Apple Daily, 21 May 2010, http://www.appledaily.com.tw/appledaily/article/forum/20100521/ 32528299 (accessed on 10 May 2016).

10. Chen-Fang Yu, "Public opinion on independence and unification in Taiwan: Is Taiwan independence the consensus?," Who Governs Taiwan Forum, 12 June 2014, http://whogovernstw.org/ 2014/06/12/fangyuchen2/ (accessed on 6 March 2017).

11. In this paper, the terms "mainland"/"China" and "Taiwan" are used for the two entities on the two sides of the Taiwan Strait, for want of any other terms that would be found acceptable by all the actors involved. "China" refers to the People's Republic of China (PRC or "the Beijing government"). "Taiwan" refers to the Republic of China (ROC or "the Taipei government").

12. Zheng Yongnian, De Facto Federalism in China: Reforms and Dynamics of Central-Local Relations, Singapore, World Scientific, 2007. 
lowing theoretical discussion of the government-business relationship, although we mainly focus on Want Want's interaction with the Chinese government, we also pay attention to Taishangs' relationships with Taiwanese lawmakers, for the reason that Taishangs' relationship with or influence on the Taiwanese government is seen as being of strategic value to the Chinese government. This point will be explained in detail through the different periods of interaction between the Chinese government and Taishangs.

Coming back to the theoretical discussion of the government-business relationship, three main approaches are discussed here, namely the society-oriented approach, system-oriented approach, and state-centred approach. (13) We argue that the business-government relationship in Taiwan, during the period from the 1990s to the present, has been a society-oriented approach, and that the dynamic of Taiwan further strengthened the business-government relationship in China under the state-centred approach. The connection between the system-oriented approach and Want Want's case is exactly the controversy over defining the capital owner's nationality in a globalised world.

\section{Society-oriented approach}

The society-oriented approach emphasises business as a powerful interest group that can constrain government bureaucrats. ${ }^{(14)}$ In order to pursue their own interests, capitalists endeavour to guide the direction of government policy through all possible channels. The core conception of the society-oriented approach lies in the "structural dependence" of the state on capital. There are two main reasons why society-oriented scholars assert the significant influence of capital owners, especially in organised interest groups putting pressure on the government. First of all, in a market-oriented society, the capital holder's investment provides a living for the majority of people. They can provide employment opportunities and subsidise government expenditure on public infrastructure. As a result, as Lindblom argues, governments must induce businesses rather than command them. ${ }^{(15)}$ There is little space for a government to refuse to offer benefits to businesses because governments need their financial support.

The second point relates to elections. In a democratic society, political parties need to be responsive to the electorate. Politicians who expect to be elected or re-elected need to consider the effects of their policies on business for the simple reason that these decisions will cause a domino effect. If the capital owners are dissatisfied with investment policies, they will withdraw their capital or initiate an investment strike, causing unemployment and financial instability in society. The society-oriented approach also emphasises capital owners as important economic and political actors because politicians rely on private businesses for political support, for instance donations and votes. Governments have the pressure of facing a trade-off with capital owners to secure their political continuance. ${ }^{(16)}$ Following the logic of this argument, it can be suggested that businesses or markets constrain the policy-making process. ${ }^{(17)}$

It can be argued that elections in China don't have any meaningful impact, as the Chinese Communist Party still holds on to power under the principle of so-called "democratic centralism." (18) As a result, it is possible to argue that business influence on the Chinese government should be less significant than in democratic countries, as the political party (the CCP) doesn't need to be responsive to the electorate. However, the society-oriented approach fits into Taiwanese society, and Taiwanese business's influence on Taiwan's legislative Yuan election is especially apparent in the period from
1994 onwards. The interaction between Taiwanese business and the Taiwanese government has transformed Taishangs into a strategic asset for the Chinese government in the expectation of political reunification.

\section{System-oriented approach}

The system-oriented approach focuses on the growing strength of the market to constrain a government's power. ${ }^{(19)}$ Scholars of the system-oriented approach argue that in the global era, national governments compete for foreign investment. ${ }^{(20)}$ The increasing speed of globalisation accelerates the pace of capital flight. The growth of technology is the main factor enhancing business power under globalisation. (21) Capital holders have more resources by which to manoeuvre or to choose their preferred investment environment. The advance of modern technology is one of the key arguments of the system-oriented approach; the removal of capital controls and the lifting of trade barriers by national governments is the other. The effects of globalisation can be viewed as limiting what governments can do and ultimately transforming the state into a weaker actor in the face of multinational capital holders. Today national policy makers do not only need to accommodate business requirements but also need to concern themselves with relevant policies in other states in order to attract multinational capital holders. The competition among states has shifted from military equipment (arms races) to retaining or attracting capital investment within their territory. ${ }^{(22)}$ The system-oriented approach is very appealing as a way of explaining the enormous power of multinational companies (MNCs). Furthermore, due to technological improvements, the nationality of capital has become much more complicated and difficult to determine. It is a topical discussion to address the nationality of capital in the globalised world. It has been argued that, in the globalised world, capital doesn't have any specific nationality as the system-oriented scholars argue; however, national governments do limit capital owners in the following respects: fiscal regimes, labour and social security, environmental regulation, and finally the currency exchange rate. ${ }^{(23)}$ This argument might well explain the Want Want case, and to a larger extent, most Taishang cases. Want Want's owner, Mr. Tsai, is of Taiwanese nationality, but his business career developed greatly

13. G. John Ikenberry, David Lake, and Michael Mastanduno, The State and American Foreign Economic Policy, Ithaca, Cornell University Press, 1988.

14. Charles E. Lindblom, Politics and Markets: The World's Political Economic Systems, New York, Basic Book Inc., 1977; Adam Przeworski and Michel Wallerstein, "Structure Dependence of the State on Capital," The American Political Science Review, Vol. 82, No. 1, 1988, pp. 11-29.

15. Charles E. Lindblom, Politics and Markets, op. cit., p. 173.

16. Adam Przeworski and Michel Wallerstein, "Structure Dependence of the State on Capital," op. cit., p. 13.

17. Charles E. Lindblom, "The Market as Prison," The Journal of Politics, Vol. 44, No. 2, 1982, p. 327.

18. Michael Waller, Democratic Centralism: A Historical Commentary, Manchester, Manchester University Press, 1981, pp. 91-102.

19. David M. Andrews, "Capital Mobility and State Autonomy: Toward a Structural Theory of International Monetary Relations," International Studies Quarterly, Vol. 38, No. 2, 1994, pp. 193-218; Joseph A. Camilleri and James Falk, The End of Sovereignty?, Aldershot, Edward Elgar, 1992; Mathew Horsman and Andres Marshall, After the Nation State, London, HarperCollins, 1994.

20. Dennis J. Encarnaion and Louis T. Wells Jr., "Sovereignty en Grade: Negotiating with Foreign Investors," International Organization, Vol. 39, No. 1, 1985, p. 48; Philip G. Cerny (ed.), Finance and World Politics: Markets, Regimes and States in the Post-hegemonic Era, Aldershot, Edward Elgar, 1993.

21. Vincent Cable, "The Diminished Nation-State:A Study in the Loss of Economic Power," Daedalus, Vol. 124, No. 2, 1995, pp. 25-26.

22. Ibid, pp. 23-53.

23. Lorraine Eden, "Taxes, Transfer Pricing, and the Multinational Enterprise," in Alan M. Rugman and Thomas L. Brewer (eds), The Oxford Handbook of International Business, Oxford, Oxford University Press, 2001, pp. 591-619. 
in China. The Want Want company as a corporation can be a global brand (or at least a cross-Strait brand), but how do we define Mr. Tsai's nationality? According to the above argument, the capital owner does have de jure nationality due to the realistic constrains of investment, (24) so Mr. Tsai should not be classified as Taiwanese but rather as a Chinese capital owner.

\section{State-centred approach}

Stephen Krasner asserts that the state should be viewed as a main actor rather than a reflection of societal characteristics or an arena for social groups to compete. ${ }^{(25)}$ Krasner recognised that the interaction between the state and social interest groups is dynamic. That is to say, the state may be strong in some areas but weak in others; the pattern will probably not be exactly the same in respect to all policy areas. That is, policy decisions are often made in arenas that respond to narrow social and economic special interest groups, for instance in relation to agricultural and domestic economic policies. ${ }^{(26)}$ In brief, the state-centred approach holds that the state has the capacity or autonomy to select its own goals, and to interact with social groups as the means to achieving these selected goals.

In combination with the state-centred approach, we emphasise that in the case of China, the government-business relationship also reflects the fact that China is a unique country with distinct characteristics of state capitalism. ${ }^{(27)}$ The CCP has steered the path of gradual, albeit uneven, integration within global capitalism, not through coercion but through different layers of close guanxi (relationship) with business groups. The core reason that China is characterised as a state capitalist economy is because the state's capacity to exert control over the market is omnipresent, and therefore business groups have to fulfil the state's goals or even more, to extend the state's goal. This can be seen very clearly in the case of Want Want. In the Analysis section of this paper, we will particularly analyse two main issues, bearing the framework of state-centred analysis in mind: the rationale for Want Want's investment in Taiwanese media, and the popular resistance to Want Want's involvement.

However, before going into a detailed analysis of Want Want's motivations for buying into Taiwan's media, we also want to explain why, among different kinds of investment, investment in media is an attractive choice to the capitalists. The media industry offers economic and socio-political benefits for media owners. The mass media market has been a major and expanding industry in the last century. In capitalist society, the media industry can generate surplus value, i.e., economic benefit. Furthermore, the media industry is also called the consciousness industry. ${ }^{(28)}$ Its products are full of social implications. In modern society, the media are the primary source of information, providing social images and defining social realities of the world. The media provide an arena where public opinions are expressed, discussed, and negotiated and where fame and celebrity status are conferred. The media are also where cultural values are constructed, stored, and expressed. ${ }^{(29)}$

Because of its social and political importance, the media industry can be an important asset for its owners for the following two reasons. Firstly, the media may be used to protect the interests of the owners or the class that the owners belong to. Numerous studies have shown that mass media tend to produce messages that reflect the interests of capital or of a particular class, and protect the interests of the media owners themselves. ${ }^{(30)}$

Secondly, the owners can use the media to build social ties with politicians who want to project favourable images through the media in order to influence public opinion; therefore, they would want to build relationships with the media owners. Thus, media owners can build ties with powerful agents and form power blocs. With these social ties, the media owner can evade laws and regulations. ${ }^{\left({ }^{11}\right)}$ Thus, with the media as important social assets, media owners can protect and advance their interests.

In many countries, media ownership has become increasingly concentrated in the hands of the rich and powerful. Over several decades, media owners have sought to expand their businesses through horizontal and vertical integration, resulting in the formation of national media groups. However, their growth was largely restricted prior to the 1990s, when national governments regulated the media industry. With the rise of neoliberal ideology in the 1990s, most national governments adopted deregulation measures and lowered restrictions on ownership and foreign investment. Thus, as media ownership became more concentrated, media groups developed into "media behemoths." Furthermore, companies outside the media industries (banks, investment companies, and other large corporate communication customers), recognising the importance of communication technology, also entered the media industry through mergers, shareholdings, and interlocking directorships. ${ }^{(32)}$ Scholars have criticised the recent deregulation and the resulting concentration of media ownership. They argue that such trends serve to reduce the diversity of information provided; consequently, the public will be poorly informed and will be restricted to a limited range of media options that protect and advance the media oligopoly's growing range of economic and political interests. ${ }^{(33)}$ In responding to those critical views, we do think Want Want could be a classic case to analyse how the country's biggest conglomerate attempted to purchase the country 's major media outlets in order to expand its political and economic interests.

\section{The growth of Want Want's investment: from Taiwan to China}

In order to explain Want Want's emergence as a massive Taiwanese investor in China, we divide Want Want's history of investment in China into four periods.

24. Morgan-Mila Marc, "Capital, Nationality and State Sovereignty: New Links for the 21st Century," conference paper at Capital Accumulation, Production and Employment: Can We Bend the Arc of Global Capital Toward Justice? World Economics Association, July 2016, http://capital2016.weaconferences.net/papers/capital-nationality-and-state-sovereignty-new-links-for-the-21st-century/ (accessed on 10 May 2016)

25. Stephen D. Krasner, "Approaches to the State: Alternatives Conceptions and Historical Dynamics," Comparative Politics, Vol. 16, No. 2, 1984, pp. 224-225.

26. Stephen D. Krasner, Defending the National Interest: Raw Materials Investment and U.S. Foreign Policy, Princeton, Princeton University Press, 1978, p. 58.

27. Jami Peck and Jun Zhang, "A Variety of Capitalism... with Chinese Characteristics?", Journal of Economic Geography, Vol. 13, 2013, p. 373.

28. Hans Magnus Enzensberger and Michael Roloff, The Consciousness Industry: On Literature, Politics and the Media, Seabury Press, 1974.

29. Denis McQuail, McQuail's Mass Communication Theory, London, Sage, 2010.

30. Vincent Mosco, The Political Economy of Communication: Rethinking and Renewal, London, Sage, 1996; Ronald V. Bettig and Jeanne Lynn Hall, Big Media, Big Money: Cultural Texts and Political Economics, Lanham, Rowman \& Littlefield Publishers, 2012.

31. For example, in Great Britain, Rupert Murdoch used his media outlets to support Conservative candidate Margaret Thatcher. After acquiring two of Britain's largest papers, Murdock attempted to buy the Sunday Times and The Times newspapers. This acquisition was forbidden by the UK's Monopoly Commission, as Murdock already had two newspapers with circulations in the millions. However, with Thatcher's support, Murdoch broke the rules and acquired the Times newspapers. Ben H. Bagdikian, The New Media Monopoly, Boston, Beacon Press, 2004, pp. 39-40.

32. Mosco, Political Economy of Communication, op. cit., p. 197.

33. Robert W. McChesney, "Global Media, Neoliberalism, and Imperialism," Monthly Review, March 2001, p. 1. Academic OneFile, http://go.galegroup.com/ps/anonymous?id=GALE\%7CA72704335 \&sid=googleScholar\&v=2.1\&it=r\&linkaccess=fulltext\&issn=00270520\&p=AONE\&sw=w\&authCount=1\&isAnonymousEntry=true (accessed on 10 May 2016). 


\section{First period: From 1987 to 1993}

Want Want started to invest in China in 1991: it belongs to the first generation of Taiwanese investment in China. Here, we argue that Taiwanese investment in China started in the early 1980s. ${ }^{\left({ }^{34}\right)}$ However, before the government of Taiwan lifted martial law in 1987, business people were completely prohibited from investing in China. After lifting martial law, the Taiwanese government gradually relaxed the controls on investment in China. ${ }^{(35)}$ The financial contribution of Taiwanese investment was the main concern for both central and local Chinese governments in this first period, and this is reflected in the interaction between Taiwanese investors and local governments.

Want Want was a medium-sized food company in Taiwan in the 1980s. The owner of the company, Mr. Tsai Eng-Meng, decided to invest in China when the country started on a path of market reform and invited foreign investment. Tsai visited China in 1991 and invested in Hunan the next year. He was attracted by the warm welcome from the local Chinese government. The flexibility of the Chinese government towards Taiwanese business is reflected in the following examples. First of all, in the early 1990s, in the Special Economic Zones (SEZs) in Guangdong, Taishangs enjoyed preferential benefits relative to other foreign investors. Those benefits included better locations for factories. As one Taiwanese businessman recalls:

When we came to this small place [one county in Dongguan] in the early 1990s, there was no decent road with asphalt, only fields of rice. The Party secretary of Dongguan promised to build a broad boulevard for transportation. In half a year's time the road was built, directly from our factory to the nearest port. ${ }^{(36)}$

Another example is land rent, which most local Chinese governments can waive for ten years in the case of Taishangs, whereas foreign investors only have a six-year rent holiday. The situation is similar in terms of tax breaks: Taishangs can enjoy a tax break for six to ten years, whereas most foreign investors only enjoy two years tax-free, with tax deductions at half the usual rate for another three years. ${ }^{(37)}$

This is similar to the situation of Tsai's investment in China during that period, but Tsai did not choose the coastal area where most Taishangs gathered. He decided to invest in Hunan Province in central China, south of the Yangtze River, mainly because the incentives provided by the local government were even better than in the coastal cities. According to Tsai, Hunan officials were very eager to cater to foreign investors and promised to meet all the demands of Want Want. They promised to build special electrical and transportation networks, to provide particular tax reductions and particular incentives for high-tech industries. Furthermore, the officials also provided administrative conveniences. ${ }^{(38)}$ In exchange, Tsai promised to invest US\$10 million in Hunan and bring job opportunities to the region. Tsai recalled that the major officials of the Party, the government, and the military at the provincial level showed up at the signing ceremony, as it was the biggest investment in Hunan up to then. ${ }^{\left({ }^{39}\right)} \mathrm{Nev}-$ ertheless, in this early period, we argue that both government (the local Hunan government) and business (Want Want) remained focused on purely economic interests. For the Hunan government, Want Want represented a huge amount of investment that would boost local economic development, so the government was very willing to provide practical support to meet the company's demands. Even for the central Chinese government, although they designed the regulations that stipulated that Taiwanese investors were entitled to more benefits than other foreign investors, ${ }^{(40)}$ they were mainly focused on attracting Taiwanese capital rather than using Taiwanese investors to accomplish the political goal of reunification in this period.

\section{Second period: From 1994 to 2000}

Want Want had a good start in Hunan. It shipped machines and staff from abroad, and earned US\$20 million in the first year, more than the revenues earned in Taiwan, and $\$ 40$ million in the second year. As a result of the social connections they had made with local leaders, Want Want was given more favours by the Hunan government; for example, building infrastructure (water, transportation, and communications) for Want Want and providing Want Want with tax reductions - favourable conditions that were originally designed for export-oriented high-technology industries, but were applied to Want Want. ${ }^{(41)}$

The reason why the central and local Chinese government kept offering Taiwanese investors special flexibility was largely due to the fact that, since the early 1990s, Taiwanese investors had been able to cultivate close relationships with Taiwanese legislators. With the help of financial donations by Taishangs to legislators during election campaigns and during legislative terms, legislative restrictions were eased by legislators under the influence of actors (Taishangs) notorious for favoring less strict conditions for investment in China. One obvious case is the authorisation of the "three small direct links" between China and the Taiwan-controlled Kinmen \& Mazu islands. Businessmen started to lobby as soon as Chen's presidency began in 2000, and legislation was swiftly passed early the following year. The same has happened with policy-making. Tse-Kang Leng shows how big Taiwanese business groups already influenced Taiwan's public policy under the presidency of Lee Teng-hui, with the example of the private airline compagny EVA:

In early 1994, Chang [president of EVA airline] began to urge the government to lift the ban on direct transportation across the Straits. In June, the MOEA's Investment Commission approved a US\$6 million plan by the Evergreen Group to build a container depot in Shanghai. ${ }^{(42)}$

Naturally mainland policy became the most popular interpellation topic

34. Yi-Wing Sung, The Emergence of Greater China, New York, Palgrave Macmillan, 2005, p. 63.

35. Charles H. C. Kao and Chu-Chia Steve Lin, "The Changing Economic Matrix between Taiwan and China," inTian-Jy Chen and Joseph S. Lee (eds), The New Knowledge Economy of Taiwan, Aldershot, Edward Elgar, 2004, p. 262.

36. Interview data (interview period 2004-2005). The interviewee was a former chairman of the Dongguan branch of the Taiwanese Business Association. The interviewee's factory manufactured toys. Interview date: 22 December 2004.

37. "To Attract Taiwanese Businessmen to China, the Mainland Gave Taiwanese Businessmen More Benefits Than Other Foreign Investors," Economic Daily, 31 May 1990.

38. Chang Dien-Wen, The Rise of Tsai Eng Meng, Taipei, Yuan-Lieu Publishing, 2012, pp. 96-100.

39. Ibid., p. 98.

40. "To Attract Taiwanese Businessmen to China, Mainland Gave Taiwanese Businessmen More Benefits Than Other Foreign Investors," art. cit:; "The CCP Will Increase Investment Benefits to Taiwanese Investors," United Daily, 22 October 1992.

41. Chang Dien-Wen, The Rise of Tsai Eng Meng, op. cit., pp. 96-99.

42. Tse-Kang Leng, The Taiwan-China Connection: Democracy and Development Across the Taiwan Strait, Boulder, Colorado, Westview Press, 1996, pp. 91-92, 
in Taiwan's Legislative Yuan in the early 1990s. For instance, one Taiwanese investor in Tianjin expressed the view, "The Tianjin government runs a 'Chinese Investment Research Seminar' monthly, and most students of this seminar are Taiwanese legislators." (43) Not only keen on attending these short-term courses organised by the Chinese government, Taiwanese legislators were also keen to study for a degree from a reputed Chinese university during this period of time. ${ }^{(44)}$ The Chinese government therefore perceived the possibility of influencing Taiwanese lawmakers by wooing Taiwanese investors. According to Tse-Kang Leng, although these legislators do not have the actual power to promulgate new laws, they certainly have effective power to lobby the executive branches. ${ }^{(45)}$ Suffice it to say that the results of these lobbying efforts are unpredictable: it depends on the fluctuating cross-Strait relationship and the businessmen-legislators' financial power. ${ }^{(46)}$ However, more and more Taiwanese investors in China can be seen as having close links with Taiwanese lawmakers, and this certainly attracted the central Chinese government's attention. Winning over the hearts and minds of Taiwanese investors therefore became a practical strategy to increase the central Chinese government's influence on Taipei's mainland policy.

Apart from Taishangs' increasing political power in the Legislative Yuan in Taipei, Taiwanese investors gradually became important envoys across the Strait. Furthermore, the semi-official channels Strait Exchange Foundation (SEF) and Association for Relations Across Taiwan Strait (ARATS) ceased interaction after 1999. Then-President Lee Teng-hui's "Two States Theory" in July 1999 contended that Taiwan is a sovereign country and that its international identity should be equal to that of the PRC. This assertion completely negated the "One China Principle." (47) The major consequence of Lee's assertion was the indefinite postponement of official talks across the Strait and of a visit to Taiwan by Wang Daohan's (then chairman of ARATS). The possibility of creating a formal negotiation channel across the Strait accordingly came to an end after the two bodies ceased their contact. In light of the declining interaction between the SEF and ARATS after 1999, both governments placed more value on the existing, but informal, channel of Taishangs as their bridge across the Strait. The Deputy Chairman of ARATS, Tang Shubei, stated explicitly in 2000 that the Chinese central government relied more on Taishangs as their bridge to the government in Taipei since negotiations could not be conducted via official channels. ${ }^{(48)}$

Secondly, the Taipei government could hardly ignore the voice of Taiwanese businesses. Taiwanese investors after 2000 increasingly influenced the Taipei government's mainland policy, not only at the legislative level but also at the policy-making level. Taiwan is in the process of consolidating democracy; therefore, government leaders rely more on the support of businesses both in running for election and in financing the government. In other words, the government-business relationship in Taiwan gradually transformed into government dependence on business people's demands. As we argued in our theoretical framework from a society-oriented business-government relation's perspective, governments have the pressure of facing a trade-off with capital owners to secure their political continuance. ${ }^{(49)}$ This is the reason why during this period, the influence of Taishangs on Taipei's mainland policy was greater than in the previous period from 1994 to 1999. Both the KMT and the DPP needed business support to run or sustain their presidency. The battles between the KMT and the DPP to win the support of Taishangs can be seen in the following example, whereby both party leaders promised a more open Mainland policy before the presidential election. After announcing his decision to stand as the KMT candidate for the 2008 presidential election, Ma Yingjeou met with Taiwanese investors and promised to offer a more open Mainland Policy under the banner of protecting Taiwan's economic security. ${ }^{(50)}$ On the same day, the DPP also held a tea party for Taiwanese investors and reported on the progress of Taipei's Mainland policy from 2004 to the present. (51)

Although there is no specific evidence to prove that Want Want built contacts with Taiwanese legislators during this period, the reason we detail Taishangs' emerging political importance in this period is to demonstrate why the Chinese government would view Taiwanese businesses as agents to achieve their political goals. Want Want, as we emphasise, is the extreme case of Taishangs being an agent for the Chinese government to achieve such goals.

\section{Third period: From 2001 to 2008}

In connection with the previous period, from 2001 to 2008, the central government kept encouraging local governments to offer special flexibility towards Taiwanese investors. ${ }^{(52)}$ In order to enter the World Trade Organisation (WTO) in 2001, the Chinese government should apply equivalent regulations to all non-Chinese investors. China officially declared that all preferential tax regulations for foreign investors, including Taiwanese investors, would be decreased in stages from 2000. ${ }^{(53)}$ In order to become a permanent member of the WTO, China was obliged to offer all WTO members equal trading privileges. This commitment to the WTO means that China cannot grant special privileges to any specific investors, including Taiwanese investors. Nevertheless, as we mentioned in the previous period, with the rapidly increasing Taiwanese investment and Taishangs' influence on Taiwan's domestic politics, the central Chinese government became increasingly aware that close economic ties across the Strait gave the Chinese government more strength in the cross-Strait relationship. According to Shen Kunrong, director of the cross-Strait Economic Development Research Centre of China's Nanjing University:

Taiwanese investment provided a richer and more solid foundation for the implementation of Beijing's policy on cross-Strait reunifica-

43. Interview data (interview period 2004-2005). The interviewee was a chairman of the Tianjin Taiwanese Businessmen Association, and the interviewee's factory was engaged in plastic manufacturing. Interview date: 1 November 2004.

44. "Zai dalu gaoxiao shenzao de taiwan 'lifa weiyuan' men" (Taiwanese Legislators studied in reputed Chinese Universities), Hua-xia News, 13 June 2001, http://big5.huaxia.com/2003627/ 00018849.html (accessed on 25 December 2016)

45. Tse-Kang Leng, The Taiwan-China Connection: Democracy and Development Across the Taiwan Strait, op. cit., p. 98.

46. Ibid.

47. Catherine Sung, "World Must Accept 'Two States': Lee," Taipei Times, 8 September 1999, p. 1.

48. Jen Ling Peng, "The Chinese Government Expect Taiwanese Businessmen to Bridge the Cross-Strait Negotiations," Economic Daily, 7 July 2000, p. 1.

49. Adam Przeworski and Michel Wallerstein, "Structure Dependence of the State on Capital," The American Political Science Review, Vol. 82, No. 1, March 1988, pp. 11-29.

50. Miao-jung Lin, "MaYing-jeou Met with Taiwanese Businessmen for the Next Presidential Election," Economic Daily, 27 February 2007, p.3.

51. Ibid.

52. Xui Zhen Liu, "The CCP Approved Taiwanese Investment by Case: The Uncertainty of Taiwanese Investment in China Increased," Economic Daily, 15 May 1996, p. 11. Interviews, Tianjin, 14 and 18 November 2004; Kunshan, 30 November and 9 December 2004; Dongguan, 20 and 23 December 2004.

53. "Special Tax Bonus Decreased Gradually: The Chinese Government Emphasized Serving Taiwanese Businessmen Rather than Offering Them Preferential Conditions," Economic Daily, 16 May 1996. 
tion than military strength. If cross-Strait economic relations keep growing, it will put pressure on the Taipei government to take a proBeijing position in their mainland policy. ${ }^{(54)}$

Taiwanese investors consequently became more important in the sense of bearing the responsibility for reunification in the central government's considerations.

The importance of Taishangs can be illustrated by the case of Want Want. In 2002 Want Want gained permission to enter other businesses, including insurance, hospitals, and restaurants, and as a result, Want Want became a conglomerate at the provincial level. Based on the Hunan model, Want Want built factories in different regions on the mainland beyond Hunan, as Tsai considered in 1994 that "the Chinese market is so vast and boundless." (55) While other provincial governments were eager to attract foreign investment, Want Want chose those provinces that provided favourable conditions, such as cheap land and buildings. In the following 13 years, Want Want established more than 100 factories and distribution networks in different regions of China. ${ }^{(56)}$ By making the most of the vast market, Want Want made big profits.

In line with the greater importance of Taiwanese businesses in China for both the central and local Chinese governments, by 2004 Want Want was deeply rooted in China, from production to consumption. First, Want Want built factories and branches in most provinces of the mainland. Second, Want Want adopted machines made in China, used its raw materials (e.g., rice), and employed Chinese workers in order to cut the cost of production and compete with emerging competitors. ${ }^{(57)}$ Third, most of Want Want's market was in China, and most of its revenues were generated from China. ${ }^{(58)}$ Fourthly, Want Want developed new products for different sectors and regions of the Chinese market. ${ }^{(59)}$ Lastly, Want Want moved its headquarters to Shanghai: the Yilan company in Taiwan was now merely a branch of the China Want Want group.

\section{Fourth period: From 2008 to 2016}

In this period, dramatic change occurred not only in the cross-Strait relationship but also in the global economic structure. There are several issues worth discussing in this context, of which the most crucial include competition with emerging local enterprises, dealing with labour issues, facing global economic recession, and finally, the KMT's return to power in Taiwan. These changes directly affected Taishangs' interaction with local officials. Most of them state that their position of "privilege" significantly declined during this period. Although Taiwanese investment is still important for local governments, Taiwanese businesses no longer seem to have such easy access to local officials. ${ }^{(60)}$ According to one Taiwanese investors in Kunshan:

In the past, we could call the mayor directly on his mobile, even at midnight. Now if we wanted to see the mayor we needed to wait for his secretary to arrange an appointment. Sometimes we had to wait for weeks. ${ }^{(61)}$

In the first period discussed above, many Taiwanese businesses enjoyed benefits from local governments, for instance tax rebates and low-cost land rental. However, after 15 years, most tax privileges were suspended. Therefore, from 2008 onwards, most Taiwanese businesses had already enjoyed this tax break. As for the land rental, at the beginning, in order to attract as much Taiwanese investment as possible, most local officials agreed to offer Taiwanese businesses extremely cheap rents. Nevertheless, their promises were unreliable, since there were no written documents or formal policies. Under these circumstances, Taiwanese businesses have had to compete not only with other foreign investors but also with domestic investors on an equal basis. Most Taishangs remark that in competition with other foreign investors, they might gain some trifling benefits because of their shared language and culture, but in competition with domestic enterprises, Taiwanese businesses don't enjoy any advantages. ${ }^{(62)}$

After the Law of the People's Republic of China on Employment Contracts (hereafter referred to as the new labour law) came into effect on 1 January 2008, many employers in China started to panic about their human resource expenditure, because this new labour law provided detailed protection for labour. ${ }^{(63)}$ For Taiwanese businesses, this was the worst possible timing. In 2008, the implementation of the new labour law meant that most Taiwanese SMEs that were benefiting from cheap labour now faced a rather challenging situation.

The KMT came back into power: for most Taiwanese businessmen in China, this was not necessarily a good thing. As Lee points out, the strategic value of Taishangs during the DPP era was far more important than in the KMT era, because Taishangs served as political agents across the Strait under Chen Shui-bian's government, but not under Ma Ying-jeou. ${ }^{(64)}$

All these changes applied to the particular case of the Want Want group's investment in China. Rightly, given all the harsh circumstances faced by Taiwanese investors after 2009, Want Want developed new practices. It began to purchase media, first in Hong Kong and then in Taiwan. This investment in the media business was different from the previous investment that Want Want had been involved in. First, in the past, Want Want had not invested in the risky media businesses; especially in 2008, the profitability and prospects of the media business were uncertain, if not gloomy. Second, Want Want had stayed in the mainland because of the low cost of production, but costs in the media business were high. Third, in the past, Tsai had not openly talked about politics, but now he did talk about politics, claiming that he had invested in Taiwan's media industry in order to strengthen the cross-Strait relationship. According to Tsai, when the pro-China KMT candidate Ma Ying-jeou won the presidency in 2008 and ended the pro-independence DPP's rule, Tsai anticipated that cooperation between the two sides of the Strait would be enhanced. He agreed with Ma's mainland policy and decided to come back to Taiwan and to enhance the understanding of Taiwanese people about mainland China. ${ }^{\left({ }^{65)}\right.}$ After buying the Want Want media

54. Bruce Gilley and Maureen Pao, "Defences Weaken," Far Eastern Economic Review, 4 October 2001.

55. Chang Dien-Wen, The Rise of Tsai Eng Meng, op. cit., p. 175.

56. Ibid, p. 183.

57. Ibid, pp. 111, 115 .

58. Ibid, p. 148.

59. Ibid, pp. 174, 229.

60. Interview data (interview period 2008-2009). The interviewee was the owner of a furniture factory. Dongguan, 22 July 2009.

61. Interview data (interview period 2008-2009). The interviewee was owner of an electronic assembly factory. Kunshan, 15 July 2009.

62. Interviews, Kunshan, 29 July 2015; Shanghai, 30 April 2014

63. Hans Hendrischke, "Changing Legislative and Institutional Arrangements Facing China's Workplace," in Peter Sheldon, Sunghoon Kim, Yiqiong Li, and Malcolm Warner (eds), China's Changing Work Place: Dynamism, Diversity and Disparity, London, Routledge, 2011, pp. 51-67.

64. Chun-Yi Lee, Taiwanese Business or Chinese Security Asset, London, Routledge, 2011.

65. "Tsai Eng Meng: My Reasons for Buying Media," Hwa Xia Net, op. cit. 
group, Tsai has continued to hold cross-Strait semi-official forums, inviting high-ranking officials and leading business figures from Chinese provinces and Taiwan. For example, Tsai established a new title - Want Daily. This paper, together with the Shanghai City government, has held annual forums ${ }^{(66)}$ to establish links between the business hubs of China and cities in Taiwan. In the forums, Taiwanese mayors were invited, the Shanghai mayor expressed his anticipation of cross-Strait communication, and the publisher Tsai, admiring the rise of China as an economic superpower, testified that he had witnessed the success of China's economic reform. ${ }^{(67)}$

\section{Analysis}

\section{Want Want's rationale for investing in Taiwanese media: Buying the media as a social asset for building political ties}

Arguably, Want Want invested in the media business mainly to build ties with CCP officials in the central government and to extend its business in China. As we argued in our theoretical section, China's economic system is state capitalist; that is, the party-state controls the flow of capital but also allocates resources to the private sector. ${ }^{(68)}$ In 2006, Want Want was expanding as an international conglomerate and would need the support of the CCP. For example, in 2006 Want Want was listed on the Hong Kong stock market; part of its stocks were bought by the state banks of China and proCCP conglomerates, including Hong Kong's richest businessman, Li Ka-shing. Want Want entered the media business when the CCP launched its "Grand Overseas Propaganda" Campaign. After the 2008 Olympic torch protest, the CCP actively co-opted Chinese capitalists to acquire media corporations in Europe and the United States. ${ }^{(69)}$ In this context, Want Want bought half the shares in Asia TV in Hong Kong in 2009. Want Want purchased the China Times Media Group (which consists of China Times and Commercial Times, and many magazine titles, a terrestrial TV station, China Television Co., and a cable news channel, CTiTV) just before the anti-Communist Apple Daily made an offer to buy the China Times Group.

Arguably, Want Want acquired the China Times group to accumulate social and economic capital in order to expand its business in China. The Want Want group owner voluntarily provided ideological services for the CCP. Tsai openly displayed his support for Beijing. He told the Washington Post in an interview that the crackdown on 4 June was "no massacre." (70) The media under the Want Want group further carried out "product placement" projects for Beijing; that is, the Want Want group received fees from the Chinese government and allocated the fees to other Taiwanese media to publicise stories favourable to China. ${ }^{(71)}$

Providing ideological services for Beijing, the Want Want media group waged wars against Taiwanese citizen groups, thus violating the social and economic principles of the media. Because the China Times Media Group consisted of different media outlets, media reform groups and some media academics were concerned about Want Want's control of Taiwan's media; they demanded that regulators should not approve the acquisition easily. ${ }^{(72}$ The Want Want group did not make any promises to Taiwanese society, for example on protecting press freedom and respecting professionalism. Instead, it filed lawsuits against citizen groups, reporters, and college professors it deemed hostile. Want Want's attack on its opponents triggered more resistance, as 149 scholars signed a petition to demand that Want Want stop the lawsuits and respect media professionalism. ${ }^{(73)}$
While losing social support in Taiwan, Want Want's owner strengthened his ties with high-ranking officials and gained social status in China. First, according to an article in Common Wealth, Want Want's owner gave a briefing to the head of China's Taiwan Affairs Office about buying Taiwan's media. The Chinese official promised to assist Want Want in doing business in China. ${ }^{(74)}$

Second, Want Want could mobilise its own media to provide positive images to Chinese officials. The media in the China Times group often offered positive images of China and different provinces of China. When officials visited Taiwan and met important people in Taiwan, they would visit Tsai at the China Times group, hoping that he would offer positive images to them.

Third, Want Want's owners became an important channel (or agents) between the powerful elites of the two countries. The China Times group, together with various Chinese local governments, hosted cross-Strait forums to discuss economic cooperation between Taiwan and China. In these forums, high-ranking Chinese officials would be presented; Want Want chose which Taiwanese politicians and business figures to invite to these important occasions. ${ }^{(75)}$

Fourth, in 2011, the Want Want group and other state enterprises received support from the Chinese government. According to a study by Fathom China, in 2013, out of 50 prominent private-sector Chinese firms, 45 received subsidies; Want Want was sixth on the list, receiving US\$11 million from the Chinese government, which was about $11 \%$ of its net profit. ${ }^{(76)}$

Finally, the owner of Want Want gained social influence in China. In 2012, Tsai was nominated one of China's most prominent figures in the economic field by China Central Television (CCTV). Only twenty Chinese were nominated; Want Want group owner Tsai was on that VIP list. ${ }^{(77)}$

These five factors identified the case of Want Want as one of mastering media as a strategic asset to gain rewards from the Chinese government in the form of facilitating its business in China. In the framework of the statecentred approach, Want Want fully complied with the Chinese government's

66. Forums between Hu (Shanghai area) and Tai (covering most cities in Taiwan), http://wantdaily.com/portal.php?mod=view\&aid=39496 (accessed on 15 May 2016).

67. Hsieh Ai-Chu, Chen Mang-Nung, and Chen Si-Hau "Shanghai- Taiwan Forum leads to communication," China Times, 3 April 2015, http://www.chinatimes.com/newspapers/20150403000843260302 (accessed on 15 May 2016).

68. Bruce J. Dickson, Wealth into Power: The Communist Party's Embrace of China's Private Sector, Cambridge, Cambridge University Press, 2008.

69. Yu-Hui Tai, "China's 'Co Clobal' Policy:The Role of Chinese Private Capitalists and Overseas Media Mergers and Acquisitions after 2008," Chinese Journal of Communication Research, No. 24, 2013, pp. 3-41.

70. Andrew Higgins, "Tycoon Tsai Eng Meng Prods Taiwan Closer to China," The Washington Post, 21 January 2012, http://www.washingtonpost.com/world/tycoon-prods-taiwan-closer-to-china/ 2012/01/20/glQAhswmFQ_story.html (accessed on 15 May 2016).

71. Lin Chou-Yi, "Chinese Officials Pay the Bills for Product Placement at China Times," Newtalk, 20 March 2012, http://newtalk.tw/news/view/2012-03-30/23697 (accessed on 15 May 2016).

72. Yu-Peng Lin (ed.), Long Road of Media Reform, 1999-2009, Taipei, Taiwan Media Watch Foundation, 2011, pp. 131-132.

73. Li-Der Chang, Yu-Lin Hsu, and Yong-Hsiang Liu, "149 Scholars Sign in against Want Want Group," Apple Daily, 17 June 2009, http://www.appledaily.com.tw/appledaily/article/forum/20090617/ 31714371/ (accessed on 15 May 2016).

74. Hsing-Fei Lin, "Sir, We Bought China Times," Common Wealth Magazine, 25 February 2009, http://www.cw.com.tw/article/article.action?id=5001838 (accessed on 10 May 2016).

75. Wu-Fu Lian, "Tsai Eng Ming Elevated to a Higher Class, Followed by Tycoons," Wealth Bimonthly, 16 March 2011, http://www.wealth.com.tw/article_in.aspx?nid=2183 (accessed on 10 May 2016).

76. "Perverse Advantage: A New Book Lays out the Scale of China's Industrial Subsidies," The Economist, 27 April 2013, http://www.economist.com/news/finance-and-economics/21576680new-book-lays-out-scale-chinas-industrial-subsidies-perverse-advantage (accessed on 10 May 2016).

77. "Tsai Eng Ming and Lin Yi Fu Nominated as 2012 Economic Figures," Apple Daily, 3 December 2012, http://www.appledaily.com.tw/realtimenews/article/new/20121203/155078/ (accessed on 10 May 2016). 
demands. Furthermore, Want Want does not just want to be granted economic benefits for its business in China. As our evidence indicates, it also seeks to be an influential Taiwanese business across the Strait, a strategically important goal for Want Want because the model of state capitalism in China can open more possibilities for Want Want's expansion in China. For the Chinese government, Want Want became an eager agent. Through the Want Want media platforms, the Chinese government met not only Taiwanese businessmen but also Taiwanese officials. It was a "win-win" situation for both the Chinese government and the Want Want group. The cost of this victory, resistance from Taiwanese society, is what we will discuss in the next section.

\section{The cost of Want Want's strategy: Local resistance}

To gain more influence in Taiwan's media industry, in autumn 2011, Want Want proposed to buy Taiwan's second largest MSO. MSOs were very important in Taiwan's media landscape. First, cable television was dominant in Taiwan, as $70 \%$ of households subscribed to cable television. Second, cable operators could decide which channels were shown and their positions on the platform. Third, cable systems were concentrated in four major MSOs; among them, China Network System Co. controlled $20 \%$ of cable subscribers. Thus, Want Want attempted to buy this MSO from a foreign investment company, MBK Partners Ltd., at a cost of US\$ 2.4 billion, the highest media merger fee in Asia. ${ }^{(78)}$ The Want Want group claimed that the merger would boost Taiwan's media industry and recover it from foreign hands.

However, because Want Want had utilised the media to please Chinese officials and to attack its opponents, some academics opposed the merger. There were three arguments against it. First, it would bring about a media monopoly and affect pluralism. The opponents argued that Want Want already owned the China Times Group, including several media outlets - two newspapers, several magazine titles, TV channels, and a terrestrial TV station; with the MSO, Want Want would interfere with other media outlets with its power to decide which channels could be broadcast via cable. Second, the applicant, Want Want, was not "fit and proper" as a television licence holder. The opponents reviewed the performance of the Want Want China Times Group over the past year and listed several actions taken by the group that they said were either illegal or unprofessional. In particular, Want Want had conducted product placement operations for the CCP; this practice was illegal. ${ }^{(79)}$ Third, there was the "China factor." Some scholars coined the term "China factor" to describe the way the rich and powerful in the cross-Strait relationship began to make alliances and to influence Taiwan's democracy and press freedom. ${ }^{(80)}$

It can be argued that this opposition was triggered by the Want Want group, as Want Want did not follow the usual principles of Taiwanese society. The reason we argue that the Want Want group is right not to take too much notice of Taiwanese society is because the Taiwanese government is not the one that Want Want as a business group will gain profit or benefit from. As we discussed under government-business relationships, we assert that the state-centred approach is more relevant to explaining our example. Here we would like to emphasise that the business group submits to the government's demands because of economic benefits that the business needed from that very government. Therefore, for the Want Want group, the Chinese government was the one that would grant them such benefits, not the Taiwanese government. This is the reason why the Want Want group presented the Chinese government with such a strategic asset: media influence over Taiwanese society. In an earlier merger, the Fubon telecommu- nications group had proposed to acquire the biggest MSO; on this occasion only a few media scholars had pointed out the danger of media monopoly. However, in the Want Want case, as Want Want did not care about the social and economic principles of Taiwanese society, but used its media to support the Chinese government and to attack its opponents at home, scholars from different disciplines (economics, law, sociology, telecommunications, and so on) mobilised against the merger. For example, scholars co-signed a statement entitled "Watch out, a media monster is threatening" in protest against the merger, demanding that the National Communications Commission (NCC) should set up a special committee to review the case carefully. (81) Later, more than 3,000 citizens signed. (82) Further, some prominent intellectuals launched a boycott against Want Want media by giving up writing columns for the China Times. At this stage, the intellectual community was mobilised against Want Want's merger.

Want Want continued to test the limits of Taiwanese society when regulators (the NCC) ruled on the merger. Based on a previous case, on 25 July 2012, the NCC ruled that there must be separation between the MSO and the news channel. (83) Both Want Want and its opponents were upset about the ruling. Want Want expected to pass unconditionally and to be allowed to control both the MSO and the news channel. The opposition demanded that the NCC reject the proposal. On the day of the ruling, several college professors submitted a petition to the NCC, urging the media regulator to reject the deal. About 200 students later appeared to protest against the merger. Two publications under the Want Want China Times Group showed pictures of the students allegedly receiving cash from an anonymous woman. ${ }^{\left({ }^{84}\right)}$ The stories then implied that one of the professors, Dr. Huang, had mobilised the students for the protest. Huang said he did not know that a group of students would show up after he left the premises. ${ }^{\left({ }^{85}\right)}$ When one National Tsing Hua University student, Chen Wei-ting, questioned Want Want's motives, he also became a target of criticism by media outlets under the group.

Because Want Want had fabricated stories to attack its opponents, young people began to realise that the media owner could openly use its media outlets as tools to attack his enemies. On 31 July 2012, hundreds of students, organised by "Youth Alliance Against the Media Monster," gathered in front of the television station of the China Times group, protesting against the Want Want Group and accusing it of violating professional journalistic values and damaging Taiwan's democracy and freedom. They demanded that the Want Want group abandon the merger. ${ }^{\left({ }^{(8)}\right.}$

78. In this deal, MBK collected more than double what it spent buying China Network's stock more than three years earlier.

79. Shelley Shan, "Experts Opposed to Want Want Merger," Taipei Times, 28 May 2012, http://www.appledaily.com.tw/realtimenews/article/new/20121203/155078/ (accessed on 10 May 2016).

80. Jieh-min Wu, "2012, the Year of China Factor," Apple Daily, 25 December 2012, http://www.appledaily.com.tw/appledaily/article/headline/20121225/34727076/ (accessed on 10 May 2016).

81. "Watch out, a media monster is threatening," http://campaign.tw-npo.org/sign.php?id= 2011101608200300 (accessed on 10 May 2016).

82. Tsung Hsin Yang, "Scholars Worried About the Media Moguls," New Talk, 9 October 2011, http://newtalk.tw/news/view/2011-10-19/18759 (accessed on 10 May 2016).

83. The NCC ruled that Want Want-China Times Group must fulfil three conditions: Want Want group chairman Tsai Eng-Meng and his family members must completely dissociate themselves from the operations of the CTiTV news channel; the operational plan for the China Television (CTV) digital news channel must be changed to make it a non-news channel; and CTV must establish an independent editorial system.

84. "The Man Behind the Protest?", China Times, 25 July 2012, p. A2.

85. Lai Yi-chuang and Lin Chau-Yi, "Huang is Regretful about China Times's Reporter," New Talk, 27 July 2012, http://newtalk.tw/news/view/2012-07-27/27635 (accessed on 10 October 2016).

86. "Want Want monster has violated journalism professionalism and ethics, and damaged Taiwan's democracy and freedom," http://idontwantwantleague.blogspot.tw/2012/12/blog-post_740.html (accessed on 10 October 2016). 
This movement reached a peak on 1 September 2012, as tens of thousands of journalists, students, academics, and social activists took to the streets of Taipei to protest against media monopolisation. Their main demands included protecting media professionalism, an apology from the Want Want China Times Group, supervision by the NCC, and ending media monopolies. ${ }^{\left({ }^{87}\right)}$ The participants made the following main points: first, they pointed out that untrammelled media moguls would threaten freedom of speech in Taiwan. Second, they demanded that the NCC take legal measures to protect media professionalism. Third, they observed that the so-called "China factor" was not only an academic term but effective in real life, influencing Taiwan's democracy, and they demanded that "the Chinese should get their dirty hands off media and journalism in Taiwan." (88)

However, Want Want did not accept the demands of the civil society groups and demonstrators; because Want Want's main interests have been on the Chinese mainland, Want Want wanted to build ties with Chinese officials, not with Taiwanese civil society groups. The demonstrators demanded that the Want Want group stop buying Taiwanese media, but Tsai Eng-Meng said he would continue to buy more and even bigger Taiwanese media, $\left.{ }^{89}\right)$ and Want Want later made an offer to buy its competing newspaper, Apple Daily. Moreover, the demonstrators demanded that the Want Want media group should foster journalistic professionalism by establishing democratic decision-making mechanisms in the newsroom, but the Want Want group totally ignored this demand.

The Want Want group was clearly either unwilling or unable to enter into real dialogue with Taiwanese civil society groups.

\section{Conclusion}

Since 2008, a new type of media investor has emerged in Taiwan. The Taiwanese businessman, Want Want's owner, who made a fortune in China, returned to Taiwan after 2008 and tried to influence Taiwan's media and politics. The Want Want group is different from previous Taishangs, who mainly focused on their own businesses, seldom returned to Taiwan, and remained apolitical. Want Want not only returned to Taiwan, but also tried to use the media as a mouthpiece of the Chinese government, even at the cost of losing the Taiwanese market and the confidence of the Taiwanese people. This paper set out to analyse the rise and the rationale of this new type of media investor.

We have tried to answer this question in the light of the business-government relationship, regarding the Chinese state as a major player in this context. We mainly adopted the state-centred approach and argued that China has distinct characteristics of state capitalism; that is, the CCP's path toward capitalism has been paved with different layers of relationships closely linked with business groups. We have also explained how capitalists could use the media as an important social asset to build ties with politicians who want to gain publicity, favourable images, and influence. These social ties can create economic benefits, particularly under Chinese state capitalism.

We have also analysed the development of Want Want in the context of Taiwanese investment in China. As we have shown, right after the Tiananmen Square Event of 4 June 1989, some foreign investors left China, and Chinese local governments were beckoning Taiwanese businessmen with many incentives to attract them. In the early 1990s, Want Want grasped this opportunity, building factories and retail outlets across many provinces, and developing various types of content for different sectors of the Chinese market. Yet, as the private sector has developed in China since 2000, the Chinese government has had to pay more attention to Chinese businesspeople. In addition to this, following China's admission to the WTO, offering special incentives to Taiwanese businesses has become more complicated due to WTO regulations. Thus, Taishangs have had to build ties with Party and government officials. In this context, to seek further expansion in China, Want Want has had to build social ties with Chinese officials.

As we have shown, to achieve this, Want Want invested in Taiwanese media as a social asset in order to build political ties on the Chinese mainland. In most cases, media tycoons use the media of a country to build social ties with politicians of that country. What is extraordinary in this case is that, in the special context of cross-Strait relations whereby the PRC has attempted to control the ROC (Taiwan), Want Want bought media concerns in Taiwan as an important social asset in order to build social ties in China and to expand its business in the Chinese mainland, even at the cost of losing markets, trust, and confidence in Taiwan. As we have seen, in doing so, Want Want also triggered resistance from Taiwanese civil society, which ultimately resulted in the failure of the merger case.

We have to reconsider the nature of this new sort of media investment, particularly as, following in Want Want's footsteps, other big Taiwanese businesses in China have also attempted to buy Taiwanese media companies. For example, Ting Hsin International Group made an offer on the same MSO (China Network System Co.). Also, HTC, a mobile phone manufacturer based in China, purchased all the shares of a major channel group, TVBS (which consists of TVBS Entertainment Channel, TVBS News, and TVBS Asia). Because of the political economy of the region, this type of media investment will continue to exist, using the media as assets to build social ties and to multiply economic benefit. Thus, we need to consider the nature of the investment: is it considered Taiwanese capital or Red capital, or a special type that is based in country A, although the owner's nationality is of country $B$ ? This is not merely a conceptual issue, but also a regulatory issue.

I Lihyun Lin is Professor at the Graduate Institute of Journalism, National Taiwan University.

Graduate Institute of Journalism, National Taiwan University, No.

1, Sec. 4, Roosevelt Road, Taipei, 10617 Taiwan

(lihyunlin@ntu.edu.tw).

I Chun-Yi Lee is Assistant Professor at the School of Politics and International Relations, University of Nottingham.

School of Politics and International Relations, Law and Social Sciences Building, The University of Nottingham, University Park, Nottingham, NG7 2RD, United Kingdom (chunyi.lee@nottingham.ac.uk).

Manuscript received on 5 June 2016. Accepted on 24 February 2017.

87. Loa Lok-sin, "Thousands Protest Media Monopoly," Taipei Times, 2 September 2012, http://www.taipeitimes.com/News/front/archives/2012/09/02/2003541753 (accessed on 10 May 2016).

88. Shelley Shan, "Want Want Deal Still in Balance," Taipei Times, 28 July 2012, http://www.taipeitimes .com/News/front/archives/2012/07/28/2003538815 (accessed on 10 May 2016).

89. Apple Daily, "Tsai Eng-Meng Says: Not Interfering in Apple Daily," 28 November, 2012, http://www.appledaily.com.tw/appledaily/article/headline/20120508/34212781/ (accessed on 1 June 2016). 